\title{
TOWARD STATE ESTIMATION OF SATELLITE-BORNE LITHIUM-ION BATTERY BASED ON LOW FREQUENCY IMPEDANCE DATA
}

\author{
Kohei Tanaka $^{(1)}$, Omar S. Mendoza-Hernandez ${ }^{(2)}$, Yoshitsugu Sone ${ }^{(1)(2)}$, \\ Seisuke Fukuda ${ }^{(1)(2)}$, Masayuki Itagaki ${ }^{(3)}$ \\ (1) SOKENDAI, School of Physical Sciences, 3-1-1 Yoshinodai, Chuo-ku, Sagamihara, Kanagawa, 252-5210 Japan, \\ tanaka.kohei@ac.jaxa.jp: \\ (2) Japan Aerospace Exploration Agency, 3-1-1 Yoshinodai, Chuo-ku, Sagamihara, Kanagawa, 252-5210 Japan \\ (3) Tokyo University of Science, Faculty of Science and Technology, 2641 Yamazaki, Noda city, Chiba, 278-8510 Japan
}

\begin{abstract}
The satellite borne batteries should be composed by safe materials if we don't want to have a risk of explosion caused by batteries. Therefore, we focused on two safe batteries. One is a lithium-ion battery with an ionic liquid electrolyte, and the other is a $\mathrm{LiFePO}_{4} / \mathrm{C}$ type lithium-ion battery. To check whether the batteries are suit for space applications or not, we demonstrate the ionic liquid type batteries and $\mathrm{LiFePO}_{4} / \mathrm{C}$ type battery in orbit by mounting on "Hodoyoshi-3" microsatellite, and test $\mathrm{LiFePO}_{4} / \mathrm{C}$ type cell on the ground at various conditions for a better understanding.

On the ground tests, AC impedance and capacity of the cells were initially measured, and charge/discharge cycling was constantly repeated at 10,23 and $45^{\circ} \mathrm{C}$. The cells were discharged by constant current (CC) protocol to DOD $50 \%$ with $1.0 \mathrm{C}$ for 30 minutes. They were then charged by a constant-current/constant voltage (CC-CV) protocol to $3.6 \mathrm{~V}$ for 65 minutes with $0.5 \mathrm{C}$. For capacity check, the cells were charged at $1.0 \mathrm{C}$ in CC$\mathrm{CV}$ mode until their charge current becomes $60 \mathrm{~mA}$, and discharged at $1.0 \mathrm{C}$ in $\mathrm{CC}$ mode to $2.0 \mathrm{~V}$ at $23^{\circ} \mathrm{C}$. The AC impedance was measured by applying $100 \mathrm{~mA}$ of $\mathrm{AC}$ oscillation over the frequency range from 0.01 $\mathrm{Hz}$ to $10 \mathrm{kHz}$ at SOC $50 \%$.

As a result, the decrease in the impedance for the charge transfer through the cycles was observed at each test condition. Furthermore, especially in over recommended charge condition at $10^{\circ} \mathrm{C}$, cells that were charged and discharged at $1.1 \mathrm{~A} / 1.1 \mathrm{~A}$ were led to internal short circuit. The results suggested that the negative electrode performed as a "lithium-ion excess" by cycles. We define "lithium-ion excess" that lithiumion happens to stay inside the negative electrode without desorption after cells discharge.
\end{abstract}

\section{INTRODUCTION}

In traditional satellite operations, batteries are controlled only by their voltage, current and temperature data, so there are issues in long-term operations because deterioration is not considered. However, it is equally important to take into account deterioration to detect true conditions as operation terms have become longer by mission requirements.

There are two main issues that make it difficult to continue satellite operations on orbit. The first is difficulty for the operators to obtain the true battery capacity since satellites do not charge or discharge for capacity checks despite the deterioration of battery capacity. The second one is that the battery internal chemical condition changes by continuing charge and discharge cycles. Therefore, battery deterioration has been a major issue for long-term operation.

Impedance helps operators to understand battery deterioration. Impedance is defined as the frequency domain ratio of the voltage to the current, as in [1]. From impedance data, operators can determine the internal chemical conditions of a battery directly. Even though there are dedicated devices to measure the impedance data on the ground, it has been difficult for satellites to add the devices because it has limitations to its size and weight. Therefore, we have to calculate impedance by using House Keeping data.

On the ground, researchers are trying to calculate impedance data from the House Keeping data. Dinh Vinh [2] monitored battery voltage and current with a higher sampling rate of over $1 \mathrm{kHz}$, and tried to calculate impedance data using the "Kalman filter" technique in his research. He obtained high frequency impedance in his research and the result was sufficient, however the sampling time was too fast to apply on satellites. T. Momma [3] tried to obtain impedance data by decreasing the temperature, for example minus $20{ }^{\circ} \mathrm{C}$, because the impedance data increases when the temperature decreases. The results showed that the impedance data could be obtained analytically by monitoring battery voltage and current. However, they were not suitable for practical use since the condition was not suitable for the utilization of the operation of satellites. In orbit, T. Yairi [4] proposed a data-driven anomaly detection framework and checked with the framework whether satellites were having trouble or not. Through those researches, the deterioration of satelliteborne battery may be able to be detected accurately. However, even if the deterioration or risk of troubles can detect while they are operating, the risk of propagation continues after the satellites end the operation because the lithium-ion batteries are a fire 
hazard due to containing oxygen. Therefore, the satellite borne batteries should be composed by safe materials if we don't want to have a risk of explosion caused by batteries.

For these reasons, we focused on two safe batteries. One is a lithium-ion battery with an ionic liquid electrolyte [5], and the other is a $\mathrm{LiFePO}_{4} / \mathrm{C}$ type lithium-ion battery [6]. The ionic liquid type batteries are safe because they have lower flammability and non-volatility. $\mathrm{LiFePO}_{4} / \mathrm{C}$ lithium-ion battery is reputable for being safe since there is no process to outgas combusted oxygen. Therefore, the batteries are suitable for space applications. Furthermore, to demonstrate that these batteries are suited for space applications, we mounted both of the batteries on the "Hodoyoshi-3" microsatellite and continue to test them in orbit.

Furthermore, to understand the $\mathrm{LiFePO}_{4} / \mathrm{C}$ type cells, we tested the cells on the ground. As a related work, Dubarry et.al, tested $\mathrm{LiFePO}_{4} / \mathrm{C}$ type cells with $0.04 \mathrm{C}$, $0.2 \mathrm{C}, 0.5 \mathrm{C}, 1 \mathrm{C}$, and $2 \mathrm{C}$ [7]. As their results, when the charge and discharge rate is over $0.5 \mathrm{C}$, the capacity increase in fist 150 cycles. Furthermore, the capacity increase when the rate increase. Therefore, we assume that $\mathrm{LiFePO}_{4} / \mathrm{C}$ type cells deteriorate in different process with the other types of lithium-ion cells [8].

In this paper, we report the overview of demonstration results about ionic liquid type batteries and $\mathrm{LifePO}_{4} / \mathrm{C}$ type batteries in the orbit, and the test results of $\mathrm{LiFePO}_{4} / \mathrm{C}$ type lithium-ion secondary cell on the ground.

\section{DEMONSTRATION IN ORBIT}

\subsection{Overview of the "Hodoyoshi-3" Microsatellite}

The "Hodoyoshi-3" microsatellite is a 60 kg-class satellite developed by the university of Tokyo and NESTRA as shown in Fig.1. Hodoyoshi-3 was successfully launched on a Dnepr rocket at the Yasny Launch Base in Russia (7:11 pm, 19 June, 2014 U.T.).

Hodoyoshi-3 satellite is an earth observation satellite, and it has mission space, called "rental space", for demonstration and we mounted a demonstration module to test the ionic liquid type battery and the $\mathrm{LiFePO}_{4} / \mathrm{C}$ type battery as shown in Fig.2.

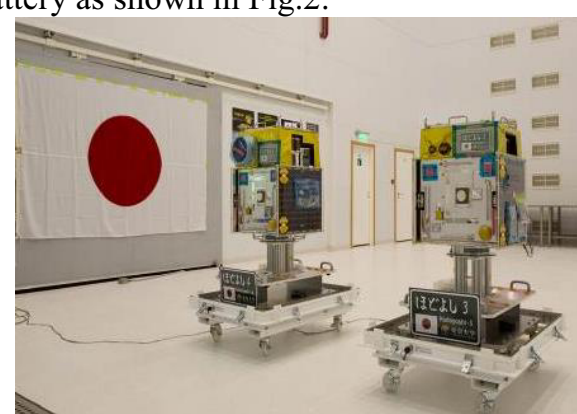

Figure1 Overview of "Hodoyoshi-3" microsatellite. The right side is "Hodoyoshi-3" and the left side is

"Hodoyoshi-4". These satellites were developed by the university of Tokyo and NESTRA.

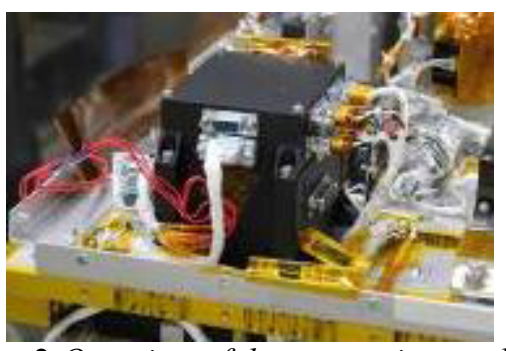

Figure2 Overview of demonstration module.

\subsection{Test results in the orbit}

The module charges with constant power $(10 \mathrm{~W})$ and discharges with constant resistance $(100 \Omega)$. The $\mathrm{LiFePO}_{4} / \mathrm{C}$ type batteries are composed of three series cells and the ionic liquid type batteries are composed of two series cells. Fig. 3 shows the test results of the $\mathrm{LiFePO}_{4} / \mathrm{C}$ type batteries and Fig. 4 shows the test results of the ionic liquid type batteries in the orbit [9]. The test condition is set as in Tab.1. Both of the batteries successfully charged and discharged, and they are still working well in orbit even after 2 years.

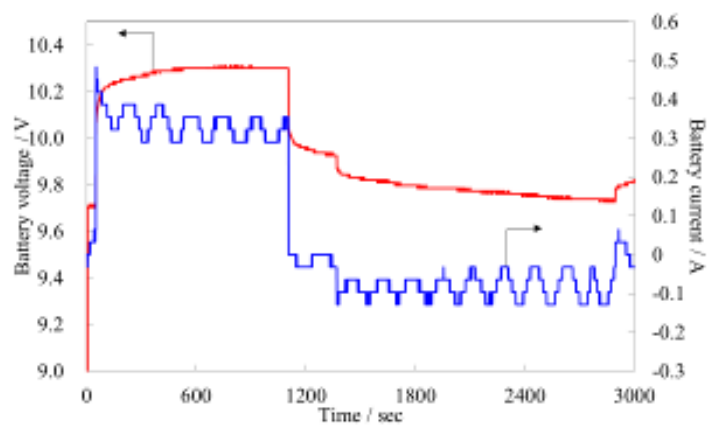

Figure 3 The charge and discharge results of the LifePO $\mathrm{P}_{4}$ type batteries.

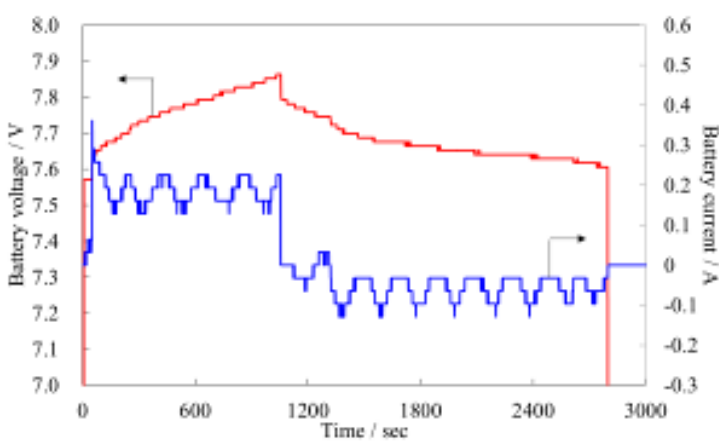

Figure4 The charge and discharge results of the ionic liquid type batteries [5].

Table1 The basic test condition of demonstration module.

\begin{tabular}{|l|l|}
\hline Time / sec & Action \\
\hline \hline 60 & Open circuit \\
\hline 600 & Charge \\
\hline 300 & Open circuit \\
\hline 1800 & Discharge \\
\hline 60 & Open circuit \\
\hline
\end{tabular}




\section{EXPERIMENTS ON THE GROUND}

\subsection{Test conditions}

To understand battery characteristics on the ground, the cell impedance is measured with an impedance analyser (NF corporation: FRA5014/As-510-ECA) and we get impedance transition data through charge and discharge cycles. The charge and discharge cycling tests are repeated with a charge and discharge test system (Kikusui electronics corporation: PFX2011). Tab.2 shows the specifications about the $\mathrm{LiFePO}_{4} / \mathrm{C}$ type cells and Fig. 5 shows appearance of the cycling tests.

Table2 Specifications about olivine-type lithium-ion

\begin{tabular}{|l|l|}
\hline \multicolumn{2}{|c|}{ secondary cells. } \\
\hline Size & 18650 \\
\hline Initial capacity & $1050 \mathrm{mAh}$ \\
\hline Operative temp. & $0 \sim 40^{\circ} \mathrm{C}$ \\
\hline Voltage range & $2.0-3.6 \mathrm{~V}$ \\
\hline
\end{tabular}

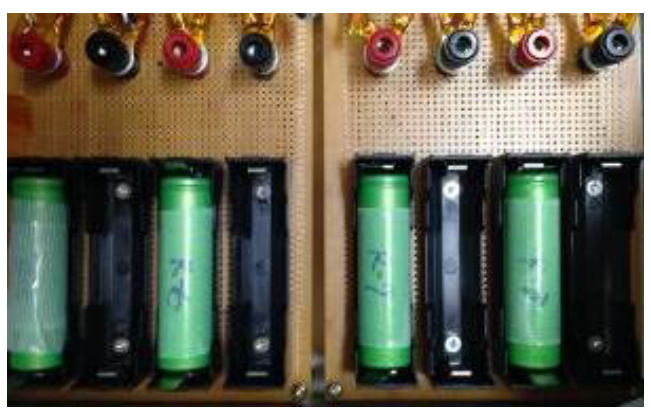

Figure5 Appearance of the cycling tests.

The effect of impedance is taken into account from temperature parameters and deterioration parameters. Therefore, to understand the cell characteristics changing, the test conditions of capacity check and cycle test were set as shown in Tab.3 and Tab.4.

AC impedance and capacity of the cells were initially measured, and charge/discharge cycling was constantly repeated at 10,23 and $45^{\circ} \mathrm{C}$. The cells were discharged by constant current (CC) protocol to DOD 50\% with 1.0 $\mathrm{C}$ for 30 minutes. They were then charged by a constant-current/constant voltage $(\mathrm{CC}-\mathrm{CV})$ protocol to $3.6 \mathrm{~V}$ for 65 minutes with $0.5 \mathrm{C}$. For capacity check, the cells were charged at $1.0 \mathrm{C}$ in $\mathrm{CC}-\mathrm{CV}$ mode until their charge current becomes $60 \mathrm{~mA}$, and discharged at $1.0 \mathrm{C}$ in $\mathrm{CC}$ mode to $2.0 \mathrm{~V}$ at $23^{\circ} \mathrm{C}$. The $\mathrm{AC}$ impedance was measured by applying $100 \mathrm{~mA}$ of $\mathrm{AC}$ oscillation over the frequency range from $0.01 \mathrm{~Hz}$ to $10 \mathrm{kHz}$ at $\mathrm{SOC}$ $50 \%$.

Table3 Capacity check condition.

\begin{tabular}{|l|l|}
\hline Charge & $\begin{array}{l}\text { CC-CV, } 1 \mathrm{C} / 3.6 \mathrm{~V}, \text { Time-cut }(2.5 \mathrm{~h}), 23^{\circ} \mathrm{C} \\
\text { Wait time } 30 \mathrm{~min} .\end{array}$ \\
\hline Discharge & $\mathrm{CC}, 1 \mathrm{C}, 2.0 \mathrm{~V}$-cut, $23^{\circ} \mathrm{C}$, Wait time $30 \mathrm{~min}$. \\
\hline
\end{tabular}

Table4 Charge and discharge cycle conditions.

\begin{tabular}{|l|l|}
\hline Charge & $\begin{array}{l}\mathrm{CC}-\mathrm{CV}, 0.5 \mathrm{C} / 3.6 \mathrm{~V}, \\
\text { It-cut }(60 \mathrm{~mA}: \max 65 \mathrm{~min} .), 10,23,45^{\circ} \mathrm{C}\end{array}$ \\
\hline Discharge & $\begin{array}{l}\mathrm{CC}, 1 \mathrm{C}, \text { Time-cut }(30 \mathrm{~min} .), \\
10,23,45^{\circ} \mathrm{C}, \text { DOD } 50 \%\end{array}$ \\
\hline
\end{tabular}

In this case, the results about capacity check are shown in Fig.6, and the test results about impedance are shown in Fig.7, Fig.8 and Fig.9 [10]. Fig.7, Fig.8 and Fig.9 show the changing of impedance through cycling tests. The cell was tested at 10,23 and $45^{\circ} \mathrm{C}$. Fig. 10 shows the discharge curve trend at capacity check.

As per the results, the decrease in the impedance for the charge transfer resistance through the cycles was observed at each test condition as shown in Fig.7, Fig8 and Fig.9. Furthermore, the capacity of cells increased at $23^{\circ} \mathrm{C}$ by cycles as shown in Fig.6. Despite of the increase of capacity, the open voltage after discharge go decrease as shown in Fig. 10.

Fig. 7 shows the Nyquist plot of tested cells at $10^{\circ} \mathrm{C}$. There are over two semi-circles in all cases. The point of intersection at high frequency indicates the electrolysis solution resistance $\left(R_{s o l}\right)$ and the radius by semi-circles indicate the charge transfer resistance $\left(R_{c t}\right)$. $R_{c t}$ becomes smaller at each test condition through charge and discharge cycles. Furthermore, especially for cells tested at $10{ }^{\circ} \mathrm{C}$, the $R_{\text {sol }}$ increased by cycles. However, the total impedance $\left(R_{s o l}+R_{c t}\right)$ consequently became smaller. We assume that the reason why the resistance becomes smaller is the lithium-ion excess to the negative electrode.

The test samples we used were $\mathrm{LiFePO}_{4} / \mathrm{C}$ type cells and the cells are said to be able to charge and discharge at a high rate without degradation. Furthermore, they have a plateau voltage at wide SOC. The negative electrode is a graphitized carbon. If there is lithium-ion excess inside the negative electrode through charge and discharge cycles, the SOC at negative electrode increases. This situation will occur if the desorption at negative electrode becomes difficult. When the SOC at negative electrode increases, the impedance gets smaller through charge and discharge cycles.

From these results, if only the charge curve trend was checked, it appears that DC resistance got bigger, so the timing of $\mathrm{CV}$ charge became earlier. However, if the impedance trend was checked also, the impedance got smaller, so we can assume that the results from Fig.6 to Fig.10 suggested that the negative electrode performed as a lithium-ion excess by cycles. Therefore, it is important to check the impedance. Furthermore, the impedance of the cells that were charged and discharged at $1.1 \mathrm{~A} / 1.1 \mathrm{~A}$ in $10^{\circ} \mathrm{C}$, which is in over limits of recommended charge condition, significantly decreased, and finally, the cells led to internal short as shown in Fig. 11. 


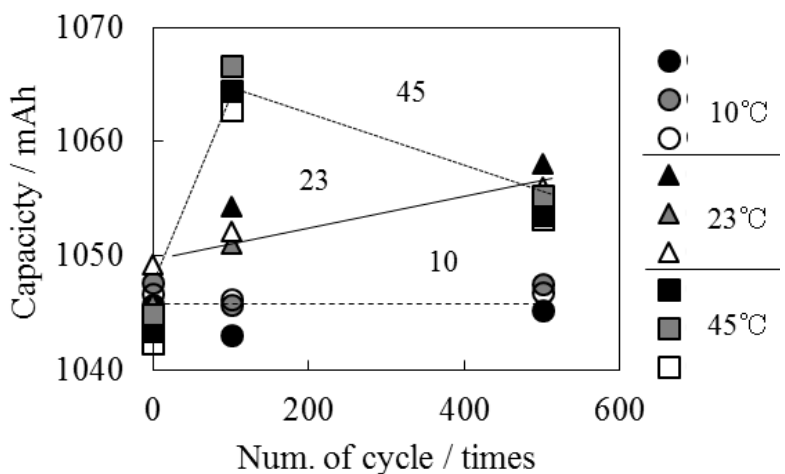

Figure6 Capacity changing of each cells. The circled data show the tested results at $10^{\circ} \mathrm{C}$. The triangled data show the tested results at $10^{\circ} \mathrm{C}[10]$.

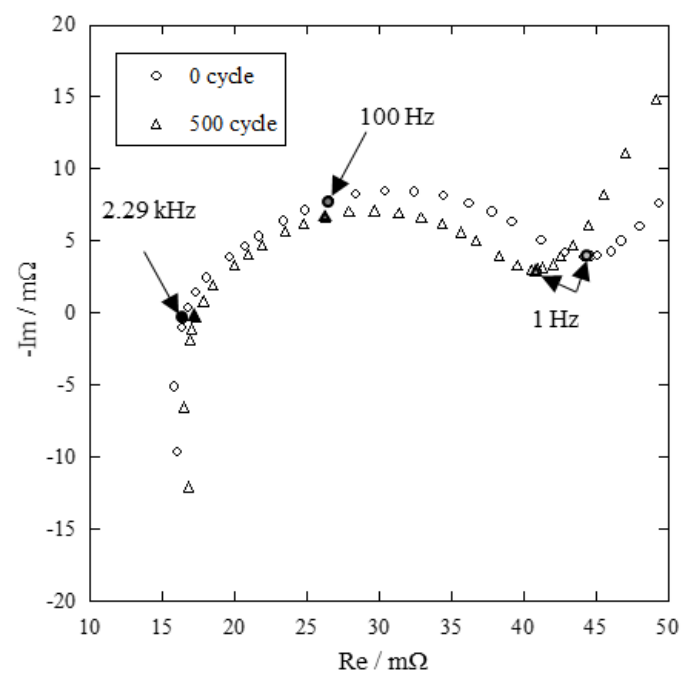

Figure7 Impedance changing through the cycling test. The impedance was measured at SOC50\% with $23{ }^{\circ} \mathrm{C}$. The cell was tested at $10^{\circ} \mathrm{C}[10]$.

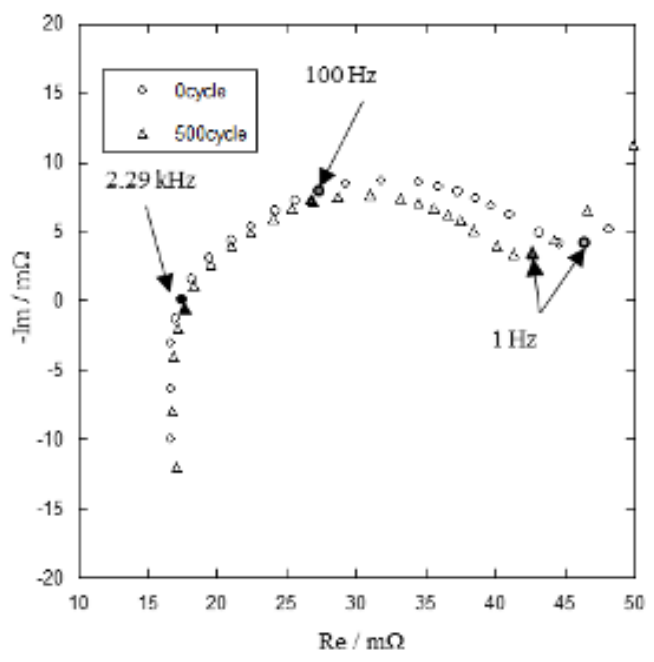

Figure8 Impedance changing through the cycling test. The impedance was measured at SOC50\% with $23^{\circ} \mathrm{C}$. The cell was tested at $23^{\circ} \mathrm{C}[10]$.

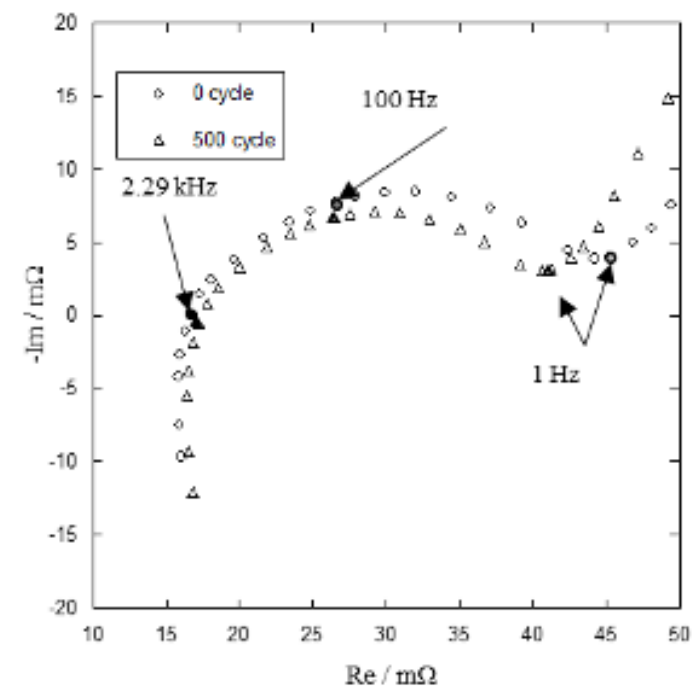

Figure9 Impedance changing through the cycling test. The impedance was measured at SOC50\% with $23{ }^{\circ} \mathrm{C}$. The cell was tested at $45^{\circ} \mathrm{C}[10]$.

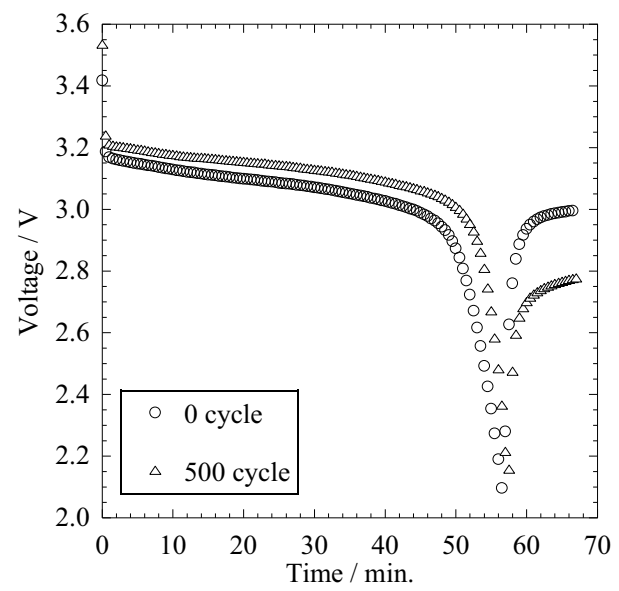

Figure10 Discharge curve trend with $1 \mathrm{C} / 23 \mathrm{deg} C$ after the cycling at $23{ }^{\circ} \mathrm{C}[10]$.

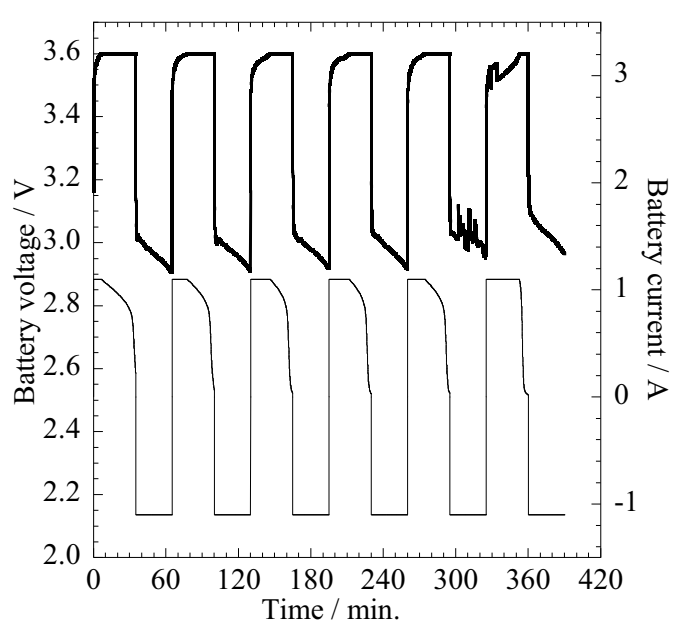

Figure10 Charge and discharge data when internal short happened [11]. 


\section{DISCUSSION}

After two years, ionic liquid type batteries and $\mathrm{LiFePO}_{4} / \mathrm{C}$ type batteries are working well in orbit. The comparative testing between ground and orbit was already conducted in the case of ionic liquid type batteries [9]. There results indicated that the cells are working well. We will test $\mathrm{LiFePO}_{4} / \mathrm{C}$ type batteries on the ground, and compare with the data obtained in orbit. On the ground, $\mathrm{LiFePO}_{4} / \mathrm{C}$ type cells are tested at 10, 23, and $45^{\circ} \mathrm{C}$. The impedance at charge transfer got smaller and the impedance at electrolyte got bigger by cycles. Furthermore, the capacity at $23^{\circ} \mathrm{C}$ continued to increase and the open voltage of discharge curve trend go decrease. As compared with Dubarry, the point that the capacity go increased was the same at $23^{\circ} \mathrm{C}$.

As a results, we assume that the balance between positive electrode and negative electrode is shifting because the negative electrode continues to stock the lithium-ion due to fail of desorption from negative electrode.

\section{CONCLUSION}

For the future space applications, we tested ionic liquid lithium ion battery and $\mathrm{LiFePO}_{4} / \mathrm{C}$ in orbit by mounting on Hodoyoshi-3 microsatellite. Both of the batteries seem to be working well after two years.

To understand the characteristics of $\mathrm{LiFePO}_{4} / \mathrm{C}$ type cells, we also tested the cells on the ground at several conditions.

In the case of over limits of recommended charge condition at $10{ }^{\circ} \mathrm{C}$, the impedance significantly decreased at low frequency, and finally, the cells led to internal short. From the results, we assume that the lithium-ion excess were observed by checking the impedance data. Therefore, it is important to check the impedance even if it is a satellite-borne battery. Furthermore, changes in impedance occurred in low frequency, so the changes will be able to detect by HK data of satellite.

\section{ACKNOWLEDGEMENT}

The cells were provided by Sony Energy Devices Corporation.

This research is partially supported by 'International Joint Research Program for Innovative Energy Technology' of Ministry of Economy, Trade and Industry (METI).

\section{REFERENCES}

1. Huet,F., (1998). A review of impedance measurements for determination of the state-ofcharge or state-of-health of secondary batteries, Journal of Power Sources, p 59-69

2. Dinh, V. D., Christophe F., Khadija E. K. B., \&
Guy F.,(2009). Impedance observer for a Li-ion battery using Kalman filter, IEEE TRANSACTIONS ON VEHICULAR TECHNOLOGY, VOL. 58, NO. 8, p3930-3937

3. Momma, T., Matsunaga, M., Mukoyama, D., \& Osaka, T., (2012). Ac impedance analysis of lithium ion battery under temperature control, J. Power Sources, 216, 304-307

4. Yairi, T., Inui, M., Kawahara, Y., \& Takata, N., (2011). Spacecraft Telemetry Monitoring Method Based on Dimensionality Reduction and Clustering, JSASS journal, Vol.59 No.691, p. 197205 (written in Japanese)

5. Yamagata, M., Tanaka, K., Tsuruda, Y., Sone, Y., Fukuda, S., Nakasuka, S., Kono, M., and Ishikawa, M., (2015). The First Lithium-ion Battery with Ionic Liquid Electrolyte Demonstrated in Extreme Environment of Space, Electrochemistry, p 918.

6. Kang, B., and Ceder, G., (2009). Battery materials for ultrafast charging and discharging, Nature, $p$ 190.

7. Dubarry, M., Truchor, C., and Liaw, B.Y., (2014). Cell degradation in commercial $\mathrm{LiFePO}_{4}$ cells with high-power and high-energy designs, Journal of Power Sources, $\mathrm{p} 408$.

8. Vetter, J., Novák, P., Wagner, M. R., Veit, C., Möller, K. C., Besenhard, J. O., Hammouche, (2005). Ageing mechanisms in lithium-ion batteries. Journal of Power Sources, p 269-281.

9. Tanaka, K., Yamagata, M., Tsuruda, Y., Sone, Y., Fukuda, S., Kono, M., Ishikawa, M.,Shirasaka, S., and Nakasuka, S., (2015). Charge and Discharge Characteristics on Orbit of High Safety Lithiumion Battery, Proceeding of Conference on Space Science and Technology (in Japanese).

10. Tanaka, K., Sone, Y., Mendoza-Hernandez, O.S., Fukuda, S., \& Itagaki, M., (2016). Typical Trend of the Impedance Spectrum Obtained from the Life Cycle Testing of the LiFePO4 type LithiumIon Secondary Cells, Electrochemistry, Vol. 84 No. 8 p. 601-604.

11. Tanaka, K., Sone, Y., Mendoza-Hernandez, O.S., Fukuda, S., \& Itagaki, M., (2016). The AC Impedance Changing of the Olivine-type LithiumIon Secondary Cells through Charge/Discharge Cycling, $67^{\text {th }}$ Annual Meeting of the International Society of Electrochemistry, 21-26, August. 